\title{
Undifferentiated Carcinoma of the Pancreas with Osteoclast-Like Giant Cells: Initially Diagnosed as Solid Pseudopapillary Tumor
}

\author{
Woohyeon Kim, In Seok Lee, Eunyoung Kim, Chul-Hyun Lim, Jin Su Kim, Yu Kyung Cho, Jae Myung Park, \\ Myung-Gyu Choi \\ Departments of Internal Medicine, Seoul St. Mary's Hospital, The Catholic University of Korea, Seoul, Korea
}

Undifferentiated carcinoma of the pancreas with osteoclast-like giant cells (UCPOGC) is a rare, highly malignant pancreatic exocrine neoplasm. Here, we report a case of UCPOGC in a 58-year-old man who presented with abdominal pain and weight loss. Abdomen computed tomography $(\mathrm{CT})$ revealed a $5 \mathrm{~cm}$ sized pancreatic body mass with peripheral enhancement. Endoscopic ultrasound (EUS)-guided biopsy of the mass suggested a solid-pseudopapillary tumor of the pancreas with a marked degenerative change. Distal pancreatectomy and splenectomy were performed. The size of the mass was $5.4 \times 4.8 \mathrm{~cm}$ and the cut surface showed necrosis and hemorrhage. A definite diagnosis of UCPOGC was made using the histopathology and immunohistochemical findings.

Korean J Pancreas Biliary Tract 2016;21(3):144-149

Keywords: Carcinoma, Undifferentiated, Osteoclast, Giant cells, Pancreas

\author{
Received Apr. 4, 2016 \\ Revised May 8,2016 \\ Accepted May 14, 2016
}

Corresponding author: In Seok Lee Department of Internal Medicine, Seoul St. Mary's Hospital, The Catholic University of Korea, 222 Banpo-daero, Seocho-gu, Seoul 06591, Korea Tel. +82-2-2258-6022 Fax. +82-2-2258-2055 E-mail; isle@catholic.ac.kr

This is an Open Access article distributed under the terms of the Creative Commons Attribution Non-Commercial License (http:/ creativecommons.org/licenses/by-nc/3.0/) which permits unrestricted non-commercial use, distribution, and reproduction in any medium, provided the original work is properly cited.

Copyright $\odot 2016$ by The Korean Journal of Pancreas and Biliary Tract

\section{INTRODUCTION}

Undifferentiated carcinoma of the pancreas with osteoclastlike giant cells (UCPOGC), first described by Juan Rosai in 1968 , is a rare, highly malignant exocrine tumor. ${ }^{1}$ UCPOGC is now classified by the World Health Organization as a rare variant of ductal adenocarcinoma, based on the epithelial origin of this tumor. In the early reports on this tumor it was suggested that they may have a more favorable prognosis compared with the usual ductal adenocarcinoma. ${ }^{2,3}$ UCPOGC tends to present at the mean age of 60 years, and has the same sex distribution. Microscopic findings consist of atypical mononuclear round cells and abundant osteoclast-like multinucleated giant cells, thus, mimicking a giant cell tumor of the bone. $^{2}$ Here, we report a case of UCPOGC and describe its characteristics.

\section{CASE}

A 58-year-old man visited our outpatient clinic due to left 
upper quadrant pain for 3 consecutive months. The pain was continuous and it radiated to the back. The patient had weight loss of $8 \mathrm{~kg}$ over a 5 -month period. He had type 2 diabetes mellitus, and was on medication for a duration of 5 months. No allergies or any significant family history was noted. On physical examination, he appeared to be chronically ill, with soft, non-tender abdomen. Vital signs were within normal range.

Complete blood counts and blood chemistries were within normal range. Carbohydrate antigen 19-9, alphafetoprotein, and carcinoembryonic cancer antigen were all normal. Ultrasonogram showed a $6.6 \times 4.9 \mathrm{~cm}$ sized hypoechoic mass in the body of the pancreas.

Abdomen CT and magnetic resonance imaging (MRI) showed a $5 \times 5 \mathrm{~cm}$ sized heterogeneous pancreas body mass with an invasion of the splenic artery and vein, abutting the common hepatic artery and portal vein (Fig. 1). There were a few enlarged lymph nodes anterior to superior mesenteric vein and at the paraaortic and aortocaval area. Positron emission tomography-computed tomography (PET-CT) revealed no distant metastasis. Pancreatic cancer was suspected and EUS-guided fine needle aspiration (FNA) and biopsy with 19 gauge ProCore needle was done for obtaining tissue.

EUS showed a hypoechoic and heterogeneous mass on the pancreas body. The pathology of the specimen obtained by EUS-guided biopsy of the pancreas showed numerous neoplastic cells with a sheet-like arrangement, several multinucleated giant cells, and hemosiderin-pigments (Fig. 2).

Immunohistochemical stain showed cells positive for alpha1-antitrypsin, vimentin, CD10 and beta-catenin, and negative
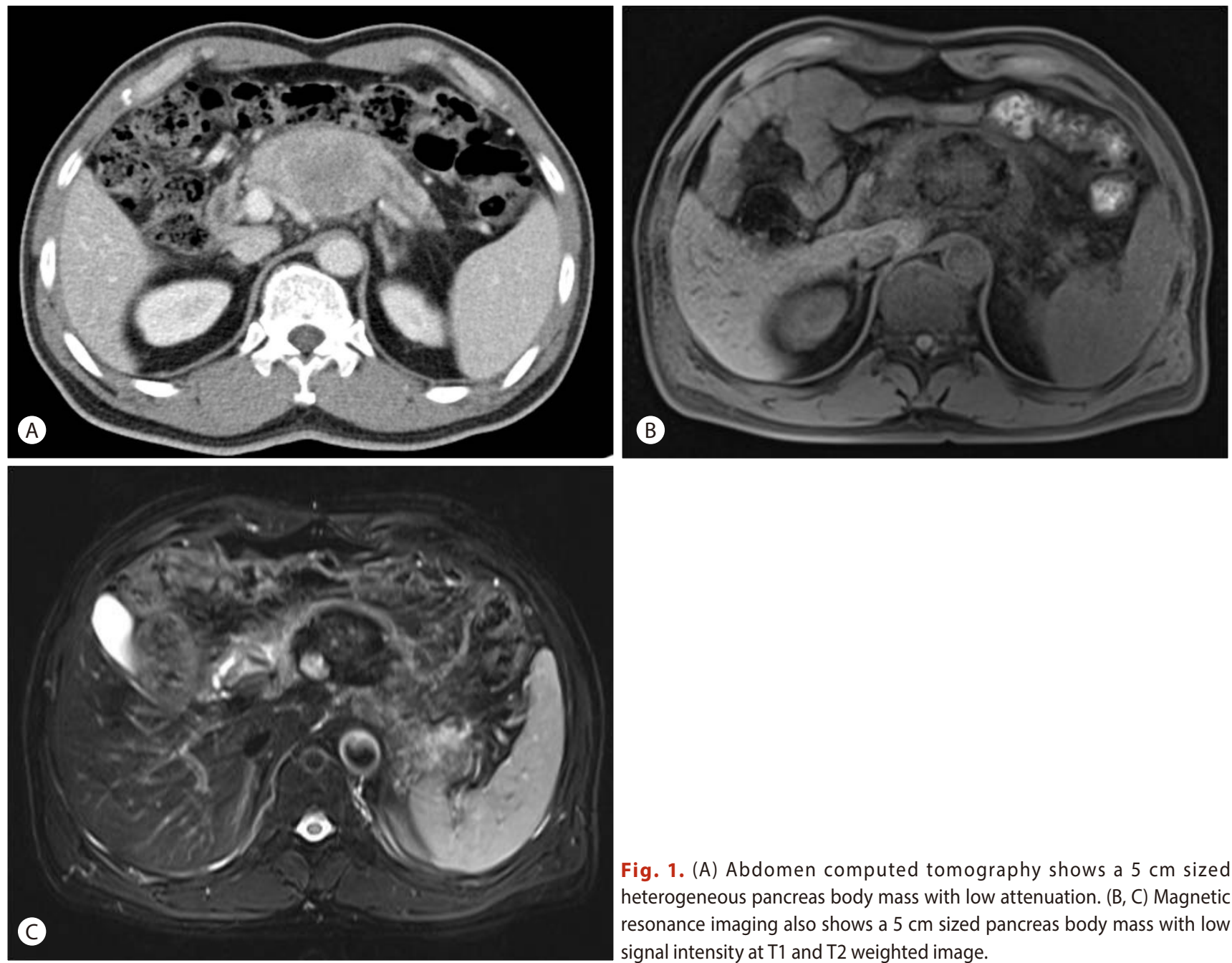

Fig. 1. (A) Abdomen computed tomography shows a $5 \mathrm{~cm}$ sized heterogeneous pancreas body mass with low attenuation. $(B, C)$ Magnetic resonance imaging also shows a $5 \mathrm{~cm}$ sized pancreas body mass with low signal intensity at $\mathrm{T} 1$ and $\mathrm{T} 2$ weighted image. 

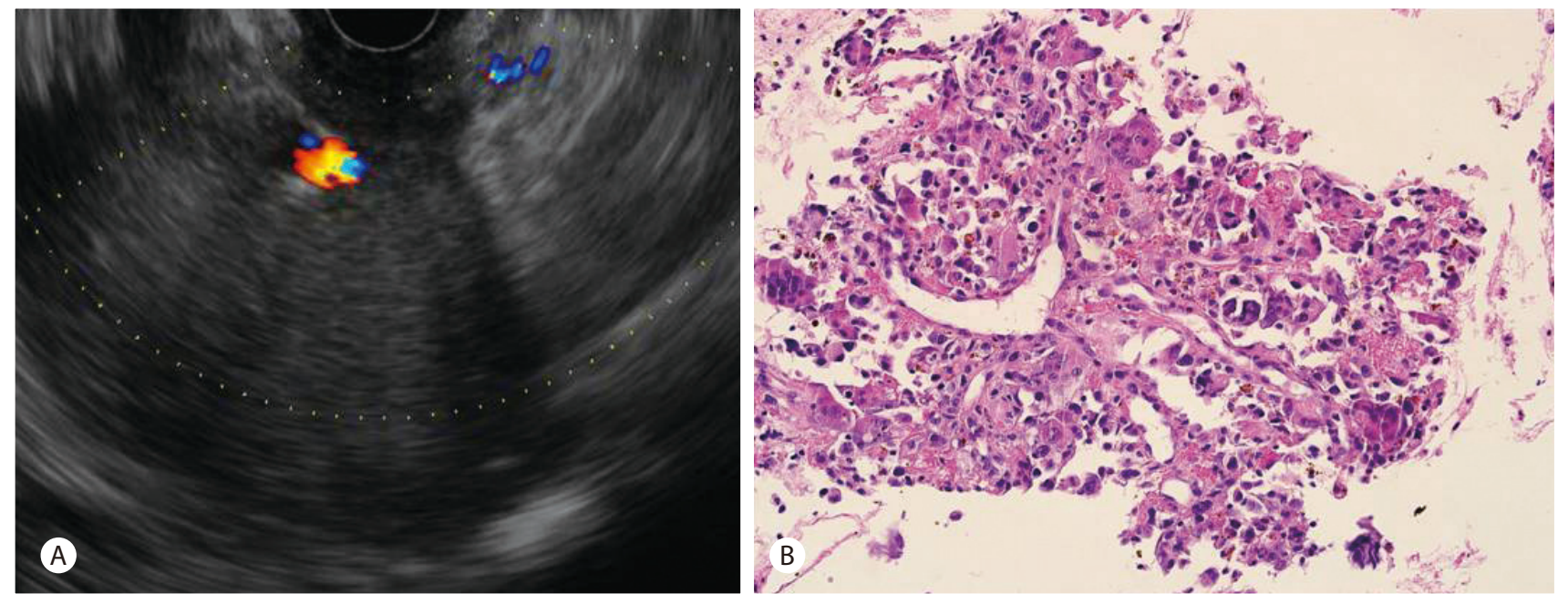

Fig. 2. EUS and microscopic finding of EUS-guided biopsy (A) Endoscopic ultrasonographic finding showing a hypoechoic and heterogeneous mass at pancreas body. (B) Microscopic finding of EUS-guided biopsy reveals numerous neoplastic cells with sheet-like arrangement, several multinucleated giant cells and hemosiderin-pigments (H\&E stain, $\times 40)$. EUS, endoscopic ultrasound.
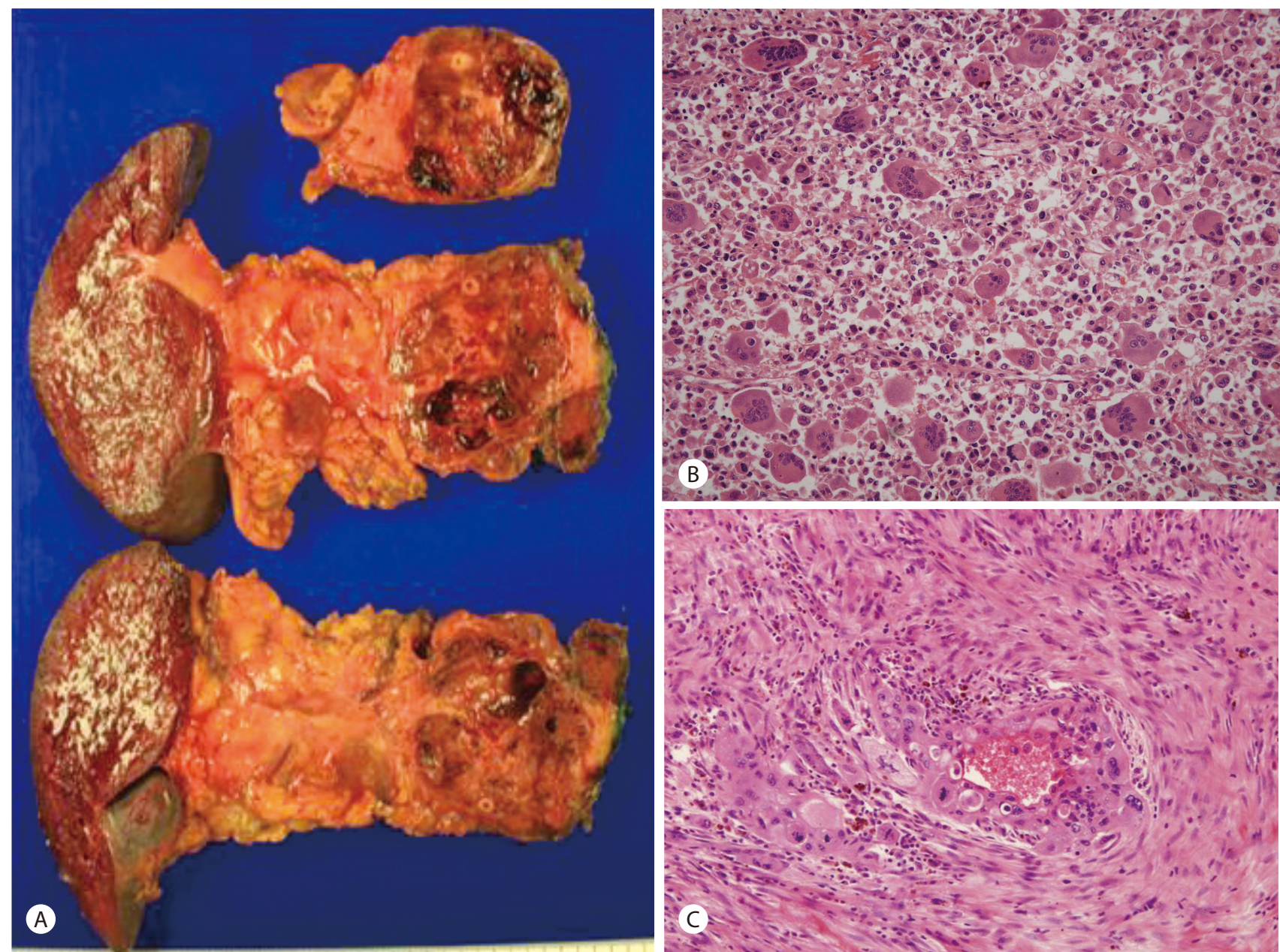

Fig. 3. Gross pathology and microscopic finding (A) Gross specimen reveals a $5.4 \times 4.8 \mathrm{~cm}$ sized mass in the pancreatic tail, composed of cystic and solid portions with necrosis and hemorrhage. (B) Atypical neoplastic mononuclear cells admixed with abundant non-neoplastic osteoclast-like giant cells (OGCs) (H\&E stain, $\times 200)$. (C) Ductal adenocarcinoma component is found (H\&E stain, $\times 200)$. 
for pancytokeratin and chromogranin. These findings sug gested solitary pseudopapillary tumor (SPT) with marked degenerative changes.

Distal pancreatectomy and splenectomy were performed. Grossly, the resected mass was $5.4 \times 4.8 \mathrm{~cm}$ in size and was composed of cystic and solid portions with necrosis and hemorrhage (Fig. 3A). The tumor arose from the pancreas tail and it extended beyond the pancreas. Resection margin involvement was absent, but lymphatic, intravascular, perivascular, and perineural invasion were noted.

Histologic study showed tumor cell components consisting of atypical neoplastic mononuclear cells admixed with nonneoplastic osteoclast-like giant cells (OGCs) on hematoxylin and eosin stain (H\&E) (Fig. 3B). The ductal adenocarcinoma component was also found in this case (Fig. 3C). On the immunohistochemical stain, OGCs were strongly positive for CD68, which are indicative of the histiocytic origin (Fig. 4A). Neoplastic mononuclear cells were positive for p53, but OGCs were negative for p53 (Fig. 4B). Pancytokeratin was also focally positive, which suggests the ductal cell origin of the undifferentiated carcinoma with OGCs (Fig. 4C). Vimentin was expressed in OGCs and neoplastic mononuclear cells (Fig. 4D). These findings were consistent with UCPOGC, and pathologic TNM staging was $\mathrm{T} 3, \mathrm{~N} 1, \mathrm{M} 0$, stage IIB according to the TNM classification $\left(7^{\text {th }}\right.$ edition) of the American Joint Committee on Cancer.

The patient received adjuvant chemotherapy with two cycles of 5-FU. However, metastatic cancer was detected on the soft tissue of the right thigh. The patient underwent palliative radiation therapy with two cycles of gemcitabine/erlotinib. Despite treatment, cancer progressed and the patient died 7 months after the initial diagnosis.

\section{DISCUSSION}

UCPOGC is a rare malignancy, which accounts for less than $1 \%$ of all pancreatic cancers. ${ }^{1}$ It is an aggressive tumor that commonly invades adjacent organs. It is observed in patients with a mean age of 60 years but there is a wide age range, usually between 32 and 82 years. No gender predilection is associ- ated with UCPOGC. ${ }^{2,4}$

The main signs and symptoms are abdominal pain, weight loss, fatigue, anorexia, and palpable mass. The CT scan shows irregular cystic and solid tumor with heterogeneous enhancement by the contrast. ${ }^{5}$ MRI findings of this tumor have not been established yet. Hur et al. ${ }^{6}$ reported UCPOGC with low signal intensity on T1-weighted image and heterogeneous high signal intensity with multifocal cystic lesions on T2weighted image. Other case reported heterogeneous high signal intensity within the mass on T1-weighted image that was thought to be a cystic hemorrhage. ${ }^{7}$ Another case showed low signal intensity on T2-weighted image. ${ }^{8}$ The explanation for these findings is not clear, but we hypothesize that various extents of hemorrhage and necrosis of this tumor contribute to diverse MRI findings. In present case, the mass showed low signal intensity on both T1- and T2-weighted MRI.

Tumor markers, CEA and CA 19-9 are less commonly elevated and not distinct. The diagnosis is usually made on surgical specimen. In some cases, EUS-FNA has shown to be effective, and an accurate diagnosis had been achieved by cytology test. $^{2,9}$

UCPOGC is classified by the World Health Organization (WHO) histologic classification system as a variant of ductal adenocarcinoma with two distinct cell lines: (1) highly pleomorphic mononuclear or multinucleated neoplastic cells and (2) large multinucleated non-neoplastic cells. ${ }^{2,10}$ Usually, multinucleated, benign-appearing OGCs are dispersed among pleomorphic mononuclear or multinucleated cancer cells. Immunohistochemical findings showed that, OGCs were positive for histiocytic marker CD68 and were negative for the epithelial marker p53. Pleomorphic mononuclear cancer cells were positive for $\mathrm{p} 53$. These findings demonstrate an epithelial origin of UCPOGC. ${ }^{2}$

The differential diagnosis of UCPOGC includes cystic lesions, such as serous cystic tumor, mucinous cystic neoplasm, intraductal papillary mucinous neoplasm, solid pseudopapillary neoplasm and ductal adenocarcinoma with cystic degeneration.

In our case, EUS-guided core biopsy was inadequate; findings revealed a sheet-like arrangement of tumor cells with a few 
multinucleated giant cells, suggestive of solid pseudopapillary tumor (SPT) with marked degenerative change; however, the surgical specimen showed p53-positive highly pleomorphic mononuclear neoplastic cells and abundant CD68-positive multinucleated OGCs on immunohistochemical stain. Characteristically, coexistence of adenocarcinoma component was also seen. Because the presence of non-neoplastic osteoclast-like giant cells is the histological hallmark of UCPOGC, we were confident to definitely conclude UCPOGC as a diagnosis. ${ }^{6}$

The prognosis of UCPOGC is poor, but it is better than that of the usual ductal adenocarcinoma. ${ }^{2,3}$ In a review of 32 cases of UCPOGC, the mean survival was 20.4 months after diag- nosis or surgery. Most of the patients died of tumor within 1 year, but the other patient survived more than 15 years. UCPOGC have better prognosis and better response to adjuvant therapy compared with undifferentiated carcinoma without OGCs, because it is slower to metastasize and rarely metastasizes to the lymph nodes. In this context, WHO classification might have separated UCPOGC from undifferentiated carcinoma without OGCs. ${ }^{11,12}$

Lung and liver metastasis were commonly reported. Peritoneum, bone, prostate and adrenal metastasis were also reported. ${ }^{12,13}$ But, there is no report of soft tissue metastasis in UCPOGC patients until now. In our case, soft tissue metasta-
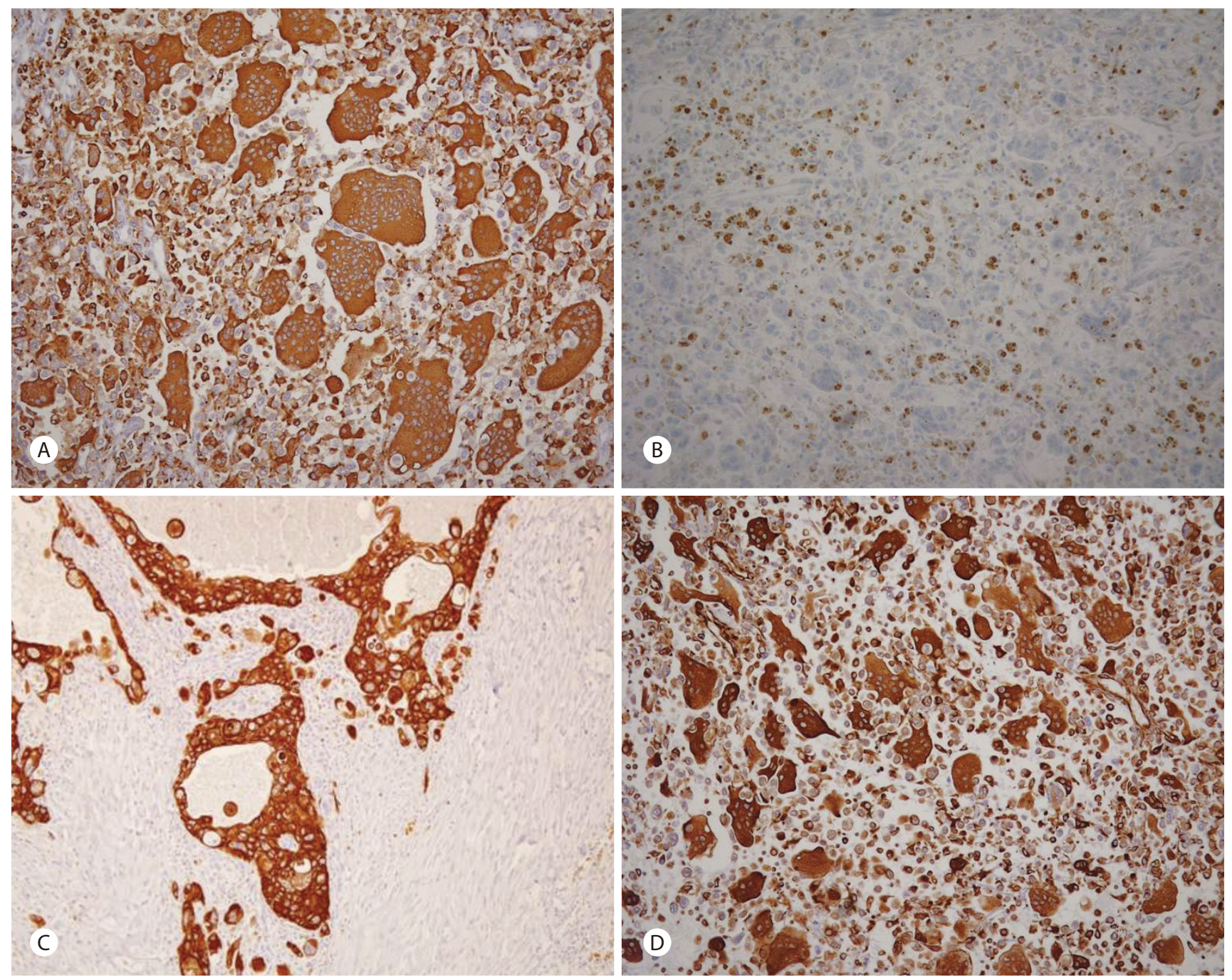

Fig. 4. Immunohistochemical staining of surgical specimen (A) Reactivity with CD68 in OGCs ( $\times 400)$. (B) Reactivity with p53 in neoplastic mononuclear cells $(\times 200)$. (C) Focal reactivity with pancytokeratin in ductal adenocarcinoma component $(\times 100)$. (D) Reactivity with vimentin in OGCs and neoplastic mononuclear cells $(\times 200)$. 
sis was proven by biopsy.

Because UCPOGC is rare, it is difficult to determine an optimal treatment modality for this tumor. It is recommended to follow the protocols established for pancreatic ductal adenocarcinoma as a treatment modality. In general, surgical en-bloc resection is considered the first line of treatment and may prolong survival. ${ }^{5,6}$ While, the efficacy of adjuvant treatments, including chemotherapy or radiotherapy, remains to be demonstrated. Recently, there was a case report of locally advanced UCPOGC patient treated by en-bloc surgical resection followed by adjuvant chemotherapy who survived more than 10year without any evidence of recurrence. ${ }^{2}$ However, further studies are needed to improve our understanding of UCPOGC.

In summary, a middle aged male with imaging studies showing a heterogeneous pancreatic mass was initially diagnosed as SPT with marked degenerative changes via EUSguided biopsy. However, surgical specimen revealed two distinct cell lines-mononuclear neoplastic cells and large multinucleated osteoclast-like giant cells. The tumor was then diagnosed as UCPOGC.

Undifferentiated carcinoma of the pancreas with osteoclastlike giant cells is a rare, highly malignant pancreatic neoplasm. It is difficult to determine an optimal treatment modality for this tumor due to its rarity. Therefore, early diagnosis and complete resection could be only chance to cure this tumor. When irregular solid and cystic pancreatic mass observed on imaging test, as it did in our case, UCPOGC should be considered in the differential diagnosis.

국문 색인: 암종, 미분화, 파골세포, 거대세포, 췌장

\section{Conflicts of Interest}

The author has no conflicts to disclose.

\section{요 약}

췌장의 파골세포양 거대세포 미분화 암종은 그 발생 빈도 는 드물지만 높은 악성도를 가지는 외분비 췌장암이다. 췌장 의 파골세포양 거대세포 미분화 암종은, 복부 전산화단층촬 영에서 괴사와 출혈을 동반한 낭성 및 고형 종괴의 소견을
보이며, 다른 췌장의 낭성 종양과 감별이 필요하다. 현재까 지 명확하게 정립된 치료법은 없으며, 조기 진단 및 종양의 완전 절제만이 생존률 향상을 가져온다고 보고되고 있다. 본 증례는 58 세 남성 환자에서 발생한 췌장의 파골세포양 거대 세포 미분화 암종이 수술 및 항암치료에도 불구하고 연조직 전이로 진행하여 사망한 1예로 문헌고찰과 함께 보고한다.

\section{REFERENCES}

1. Rosai J. Carcinoma of pancreas simulating giant cell tumor of bone. Electron-microscopic evidence of its acinar cell origin. Cancer 1968;22:333-344.

2. Gao HQ, Yang YM, Zhuang Y, Liu P. Locally advanced undifferentiated carcinoma with osteoclast-like giant cells of the pancreas. World J Gastroenterol 2015;21:694-698.

3. Bosman FT, Carneiro F, Hruban RH, Theise ND. WHO Classification of Tumours of the Digestive System. $4^{\text {th }}$ ed. Lyon, France: IARC Press, 2010.

4. Lukás Z, Dvorák K, Kroupová I, Valásková I, Habanec B. Immunohistochemical and genetic analysis of osteoclastic giant cell tumor of the pancreas. Pancreas 2006;32:325-329.

5. Njoumi N, Elalami FH, Attolou G, et al. Undifferentiated pancreatic carcinoma with osteoclast-like giant cells: a case report. J Gastrointest Cancer 2014;45:96-98.

6. Hur YH, Kim HH, Seoung JS, et al. Undifferentiated carcinoma of the pancreas with osteoclast-like giant cells. J Korean Surg Soc 2011:81:146-150.

7. Kim GH, Ku YS, Kim HO, et al. A case of undifferentiated carcinoma with osteoclast-like giant cells of the pancreas. Korean J Med 2009:77:610-615.

8. Farah F, Mlika M, Eddiba T, Zermani R, Jilani SBB. Undifferentiated Carcinoma with Osteoclast-Like Giant Cells of the Pancreas (A Case Report). Open Access Sci Rep 2012;1:179.

9. Moore JC, Hilden K, Bentz JS, Pearson RK, Adler DG. Osteoclastic and pleomorphic giant cell tumors of the pancreas diagnosed via EUSguided FNA: unique clinical, endoscopic, and pathologic findings in a series of 5 patients. Gastrointest Endosc 2009;69:162-166.

10. Shah A, Khurana T, Freid L, Siddigui AA. Undifferentiated carcinoma with osteoclast-like giant cells of the pancreas in a patient with new diagnosis of follicular non-hodgkin's lymphoma. ACG Case Rep J 2014;1:109-111.

11. Jo S. Huge undifferentiated carcinoma of the pancreas with osteoclast-like giant cells. World I Gastroenterol 2014;20:2725-2730.

12. Shiozawa M, Imada T, Ishiwa N, et al. Osteoclast-like giant cell tumor of the pancreas. Int J Clin Oncol 2002;7:376-380.

13. Tezuka K, Yamakawa M, Jingu A, Ikeda Y, Kimura W. An unusual case of undifferentiated carcinoma in situ with osteoclast-like giant cells of the pancreas. Pancreas 2006;33:304-310. 